\section{Stub Length and Stub Angle Did Not Influence Renewal Shoot Number or Branch Angle of Tall Spindle 'Gala'/Malling 9 Apple Trees}

\author{
James R. Schupp ${ }^{1}$, H. Edwin Winzeler, and Melanie A. Schupp
}

AdDITIONAL INDEX WORDs. dormant pruning, Dutch cut, M.9, pruning automation, renewal growth

SUMMARY. Renewal of limbs by pruning to leave a short, angled, upward-facing stub is common practice for spindle-type apple (Malus $\times$ domestica) training systems. A short, beveled stub cut is thought to stimulate renewal growth from latent buds present underneath the base of the excised branch, and to stimulate smaller, more fruitful renewal limbs with wide crotch angles. We conducted trials over the course of 2 years that involved dormant pruning of 'Buckeye Gala' with renewal cuts to compare two stub lengths, 0.5 and $2 \mathrm{~cm}$, and three stub orientations, upward facing, downward facing, and vertical facing, to determine the effects on renewal shoot number, position, angle, and length. We found no clear advantages with either stub length that we evaluated, and there was no improvement in renewal shoot quality with a bevel cut at any orientation. Stub length and stub angle did not influence limb renewal and may be unimportant for training orchard-pruning crews and for machine-learning and robotic pruning.

$\mathrm{F}$ erree and Schupp (2003) described two kinds of pruning cuts. Thinning cuts, whereby the limb is entirely removed, limit the possibility of regrowth by excision of all axillary buds and thin the canopy. With heading cuts, a portion of the limb is retained and the attendant axillary buds allow release from apical dominance, resulting in localized stimulation of branching.

Stubbing is a type of heading cut whereby only a small section of a 2-year-old or older limb is retained to limit the potential branching to a few latent axillary buds near the origin of the limb. Short stub cuts are recommended for spindle-type apple tree training to stimulate the regrowth of new lateral branches, to restrict the canopy volume and branching density, and to maintain favorable distribution of sunlight

Received for publication 30 Oct. 2018. Accepted for publication 12 Dec. 2018.

Published online 31 January 2019.

Department of Plant Science, The Pennsylvania State University, Fruit Research and Extension Center, 290 University Drive, Biglerville, PA 17307

The authors gratefully acknowledge funding support from the USDA NIFA Specialty Crop Research Initiative (grant no. 2012-51181-19878) and the State Horticultural Association of Pennsylvania, which provided project matching funds.

${ }^{1}$ Corresponding author. E-mail: jrs42@psu.edu.

This is an open access article distributed under the CC BY-NC-ND license (https://creativecommons.org/ licenses/by-nc-nd/4.0/).

https://doi.org/10.21273/HORTTECH04218-18 throughout the canopy (Oberhoffer, 1990; Robinson, 2003; Wertheim, 1968). Stubbing, or renewal pruning, is also beneficial for reducing the fruiting capacity of apple and is an important step in crop load management (Kon et al., 2018; Schupp et al., 2017).

Wertheim (1968) recommended that limbs should be removed, thus leaving a stub with an upward-facing bevel to stimulate a shorter, weaker wide-angle branch to develop from the lower side of the stub (Fig. 1). In most cases, such a wide-angle branch tends to be more fruitful and is preferred to an upright branch with more vigorous vegetative growth. This beveled stub cut, often referred as a "Dutch cut" (Ferree and Schupp, 2003) in recognition of the early development of spindle training and pruning systems in The Netherlands, has often been recommended for spindle-style trees (Crassweller et al., 2005; Robinson, 2003; Schupp, 2013). To our knowledge, there has never been a study of stub angle or length that has shown that a short stub with an upward-facing bevel is the optimal technique for obtaining new fruiting lateral branches with a more horizontal branch angle and low vigor.
This study evaluated short bevel cuts for limb renewal and the effects of renewal cuts at three angles and two stub lengths on renewal shoot number, position, angle, and length of dormant pruned apple trees.

\section{Materials and methods}

Ten tall spindle 'Gala' / Malling 9 (M.9) apple trees with uniform size and vigor were pruned during dormancy, using renewal cuts to remove limbs. Six stub treatments were applied to 10 (2014) or 16 (2015) branches with diameters of 9 to 14 $\mathrm{mm}$. Treatments were short $(0.5 \mathrm{~cm})$ or long $(2.0 \mathrm{~cm})$ stubs with: 1) cut face perpendicular to the pruned branch cross-section; 2) cut face with an upward-facing bevel, such that $15 \mathrm{~mm}$ more branch tissue remained at the bottom (i.e., a standard "Dutch cut"); or 3) a downward-facing bevel, such that $15 \mathrm{~mm}$ more branch tissue remained at the top (Fig. 2). Treatments were performed in a completely random design with a two-by-three factorial structure.

The number of renewal shoots (vegetative regrowth $>2 \mathrm{~cm}$ ) from each cut, the angle of the renewal shoots from the horizontal position (Fig. 3A), and the length of the renewal shoots were measured after the completion of seasonal vegetative growth. The positions of the origin of the renewal shoots around the circumference of the cut were recorded (Fig. 3B).

\section{Results and discussion}

Although renewal growth was apparent with all stubbing treatments, there were no differences in shoot number, shoot length, or renewal shoot branch angle during either year among treatments (Table 1). In 2014, stubs with a downward-facing bevel produced more renewal shoots that originated from the top of the cut surface, and $2-\mathrm{cm}$ stubs yielded more renewal shoots that emerged from a horizontal position (Table 2). Neither stub length nor cut angle affected the origin of renewal shoots at any

\begin{tabular}{llll}
\hline $\begin{array}{l}\text { Units } \\
\begin{array}{l}\text { To convert U.S. to SI, } \\
\text { multiply by }\end{array}\end{array}$ & U.S. unit & SI unit & $\begin{array}{l}\text { To convert SI to U.S., } \\
\text { multiply by }\end{array}$ \\
\hline 2.54 & inch(es) & $\mathrm{cm}$ & 0.3937 \\
25.4 & inch(es) & $\mathrm{mm}$ & 0.0394
\end{tabular}




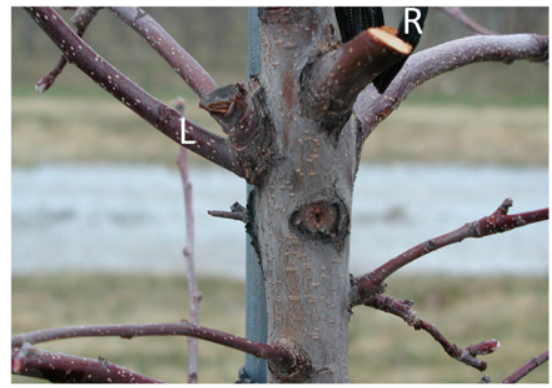

Fig. 1. Traditional upward-facing beveled renewal cuts $(L=$ showing branch renewal after 1 year; $R=$ newly cut) on apple trees in a high-density orchard in Pennsylvania. The short stub cuts are thought to promote branch renewal.

other position, and there were no differences in the renewal shoot origin in 2015.

Our study was conducted on 'Gala', which is a moderately vigorous cultivar of a spreading type III growth habit [Lespinasse (as described by Ferree and Schupp, 2003)]. Trees with different levels of vigor and different growth habits may differ in response to renewal stub cuts. However, this requires additional study.

\section{Conclusion}

No advantages were observed when using a stub length of 0.5 to $2 \mathrm{~cm}$. Furthermore, there was no improvement in renewal shoot quality when a bevel cut was used. Creating the renewal cut in the traditional way requires precise placement of the cutting blades. Although this placement is not especially time-consuming for skilled orchard workers, it does require training for novices.

There is growing interest in automating labor-intensive horticultural practices, including dormant pruning (Herrick, 2017). Precise placement of the cutting-end effector would require extra steps and more sophisticated vision systems if engineers were to develop robotic pruning systems for apple trees. Perpendicular renewal cuts are as effective as upward-facing "Dutch cuts" for stimulating desirable renewal branches and creating smaller wounds, which should facilitate rapid healing. Furthermore, to lessen the risk of infection by pathogens, shorter cuts are preferable to leaving a longer stub (Shigo, 1990).

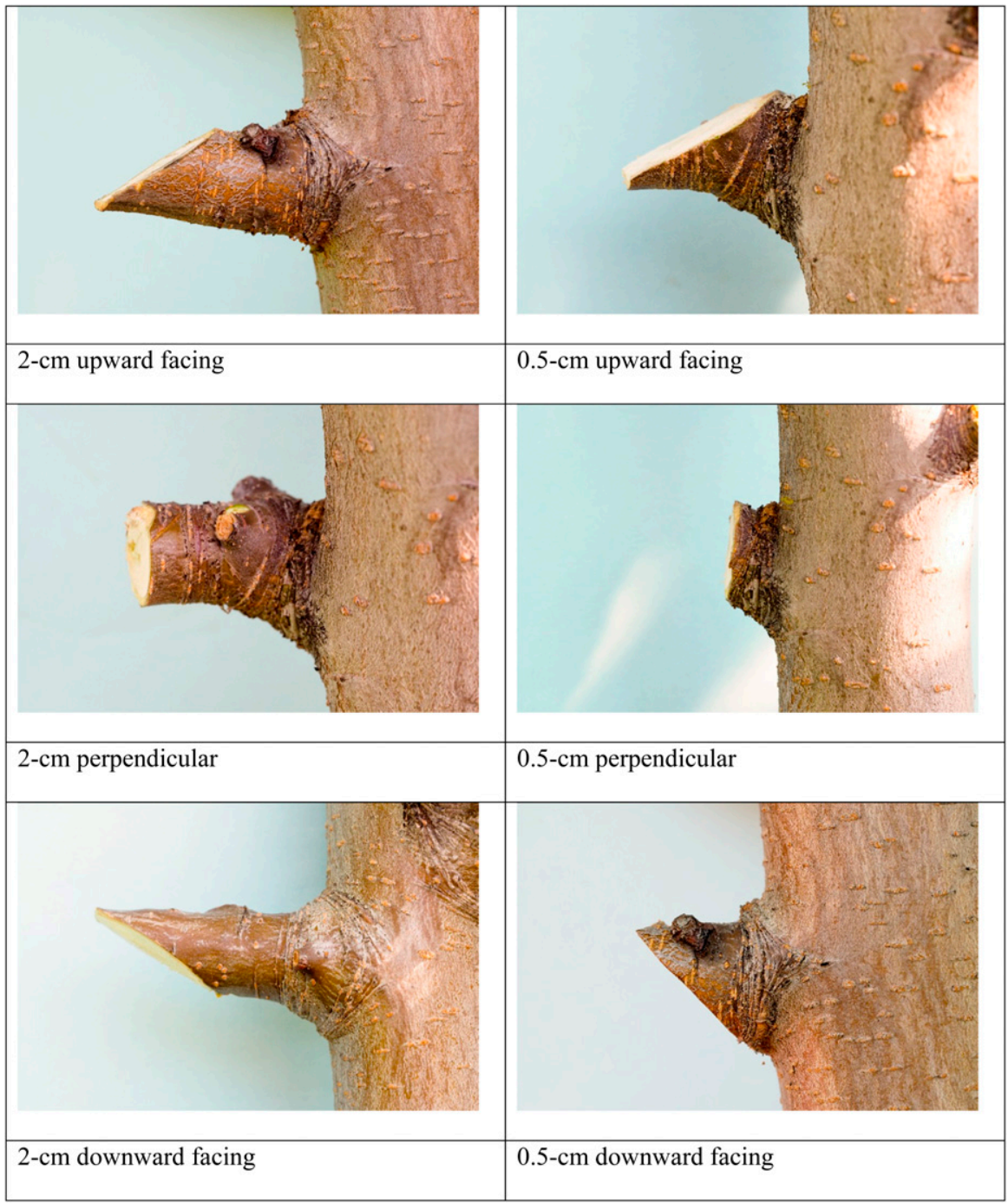

Fig. 2. Long and short stub treatments with a cut surface at three different angles in a high-density apple orchard in Pennsylvania; $1 \mathrm{~cm}=0.3937 \mathrm{inch}$.

A
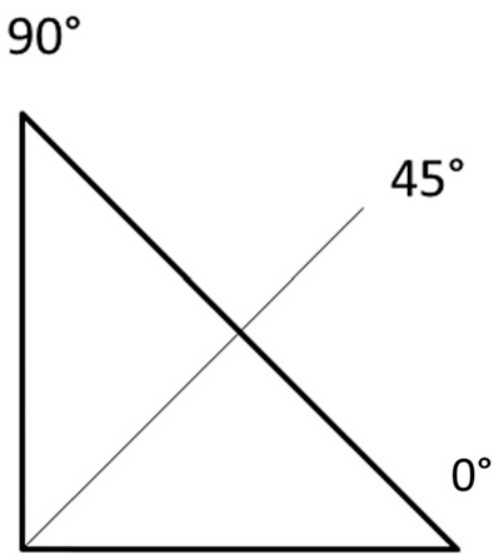

Fig. 3. Renewal shoot angle was measured from the origin horizontal to the orientation of the apple trunk (A) after pruning during the previous dormant season to leave a stub. The positions of the origin of the renewal shoots around the circumference of the cut were assigned a value from 1 to 5 , with low numbers representing orientations near the top of the cut and higher numbers representing orientations near the bottom of the cut $(B)$. 
Research Reports

Table 1. Effects of renewal stub length and stub angle on renewal shoot number, length, and branch angle of 'Gala' / $M .9$ apple trees.

\begin{tabular}{|c|c|c|c|c|}
\hline $\begin{array}{l}\text { Stub } \\
\text { length }(\mathrm{cm})^{\mathrm{z}}\end{array}$ & Cut angle & $\begin{array}{l}\text { Renewal shoots originating } \\
\text { per position (no./10 cuts) }\end{array}$ & Shoot length $(\mathrm{cm})$ & Renewal angle $\left({ }^{\circ}\right)$ \\
\hline & & 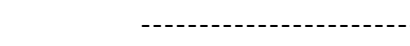 & --2014 & --- \\
\hline 0.5 & Perpendicular & 11 & 26 & 31 \\
\hline 0.5 & Down & 13 & 45 & 39 \\
\hline 2.0 & Perpendicular & 9 & 29 & 20 \\
\hline & $P$ value & & & \\
\hline & Stub length & 0.57 & 0.66 & 0.18 \\
\hline & Cut angle & 0.47 & 0.46 & 0.64 \\
\hline & Interaction & 0.47 & 0.07 & y \\
\hline & & . & 2015 - & --- \\
\hline 0.5 & Perpendicular & 8 & 48 & 33 \\
\hline 2.0 & $\mathrm{Up}$ & 9 & 53 & 27 \\
\hline \multirow[t]{5}{*}{2.0} & Down & 11 & 56 & 31 \\
\hline & $P$ & & & \\
\hline & Stub length & 0.14 & 0.23 & 0.82 \\
\hline & Cut angle & 0.76 & 0.98 & 0.79 \\
\hline & Interaction & 0.62 & 0.63 & y \\
\hline
\end{tabular}

${ }^{\mathrm{z}} 1 \mathrm{~cm}=0.3937$ inch.

${ }^{y}$ Could not test for interaction because data representing interactions included too few renewal limbs.

Table 2. Effects of renewal stub length and stub angle on the orientation of the shoot origin on the stub circumference of 'Gala'/M.9 apple trees.

\begin{tabular}{|c|c|c|c|c|c|c|}
\hline \multirow{2}{*}{$\begin{array}{l}\text { Stub } \\
\text { length }(\mathrm{cm})^{\mathrm{z}}\end{array}$} & \multirow[b]{2}{*}{ Cut angle } & \multicolumn{5}{|c|}{ Renewal shoots originating per position (no./10 cuts) } \\
\hline & & Straight up & Side up & Horizontal & Down side & Straight down \\
\hline & & & & -101 & & -- \\
\hline 0.5 & $\mathrm{Up}$ & 2 & 2 & 2 & 1 & 2 \\
\hline 0.5 & Down & 5 & 4 & 0 & 0 & 4 \\
\hline 2.0 & Perpendicular & 0 & 0 & 5 & 2 & 2 \\
\hline & $P$ & & & & & \\
\hline & Stub length & 0.08 & 0.80 & 0.03 & 0.33 & 0.21 \\
\hline & Cut angle & 0.01 & 0.16 & 0.47 & 0.47 & 0.74 \\
\hline & Interaction & 0.88 & 0.32 & 0.84 & 0.38 & 0.50 \\
\hline & & & & 201 & & \\
\hline 2.0 & $\mathrm{Up}$ & 0 & 2 & 2 & 4 & 2 \\
\hline \multirow[t]{5}{*}{2.0} & Down & 2 & 1 & 3 & 3 & 1 \\
\hline & $P$ & & & & & \\
\hline & Stub length & 1.00 & 0.18 & 0.53 & 0.66 & 0.24 \\
\hline & Cut angle & 0.47 & 0.75 & 0.43 & 0.52 & 0.14 \\
\hline & Interaction & 0.38 & 0.75 & 0.40 & y & 0.22 \\
\hline
\end{tabular}

${ }^{\mathrm{z}} 1 \mathrm{~cm}=0.3937$ inch.

${ }^{\mathrm{y}}$ Could not test for interaction because data representing interactions included too few renewal limbs. 


\section{Literature cited}

Crassweller, R., J. Schupp, and T. Baugher. 2005. Cookbook guidelines for apple training systems. 27 Nov. 2018. <https://extension.psu.edu/appletraining-systems-cookbook-guidelines $>$.

Ferree, D.C. and J.R. Schupp. 2003. Pruning and training physiology, $\mathrm{p}$. 319-344. In: D.C. Ferree and I.J. Warrington (eds.). Apples: Botany, production and uses. CABI, Wallingford, UK.

Herrick, C. 2017. Pruning goes high-tech. Amer. Fruit Grower 2017(June):6-7.
Kon, T.M., J.R. Schupp, K.S. Yoder, L.D. Combs, and M.A. Schupp. 2018. Comparison of chemical blossom thinners using 'Golden Delicious' and 'Gala' pollen tube growth models as timing aids. HortScience 53:1143-1151.

Oberhoffer, H. 1990. Pruning the slender spindle. Province British Columbia, Ministry of Agriculture Fisheries, Victoria, BC, Canada.

Robinson, T.L. 2003. Apple-orchard planting systems. p. 345-407. In: D.C. Ferree and I.J. Warrington (eds.). Apples: Botany, production and uses. CABI, Wallingford, UK.

Schupp, J.R. 2013. Renewal pruning for high density apple plantings. 27 Nov. 2018. <http://extension.psu.edu/ plants/tree-fruit/news/2013/renewalpruning-for-high-density-appleplantings $>$.
Schupp, J.R., H.E. Winzeler, T.M. Kon, R.P. Marini, T.A. Baugher, L.F. Kime, and M.A. Schupp. 2017. A method for quantifying whole-tree pruning severity in mature tall spindle apple plantings. HortScience 52:1233-1240.

Shigo, A.L. 1990. Tree branch attachment to trunks and branch pruning. HortScience 25:54-59.

Wertheim, S.J. 1968. The training of the slender spindle. Pub. No. 7. Proefstation Voor De Fruiteelt, Wilhelminadorp, The Netherlands. 